\title{
Whorephobia in Higher Education: a reflexive account of researching cis women's experiences of stripping while at university
}

\author{
Jessica Simpson ${ }^{1}$ \\ Accepted: 9 August 2021 / Published online: 3 September 2021 \\ (C) The Author(s) 2021
}

\begin{abstract}
This is a reflexive account of carrying out 'dirty research' on cis women's experiences of working as erotic dancers while at university in the UK. Focusing on the recruitment process, I discuss how universities avoided becoming 'subjects' of research by blocking the study and labelling it 'extremely sensitive' or 'inappropriate'. By scrutinising the fieldwork, this revealed the prevalence of whorephobia within Higher Education and the general, rather than idiosyncratic, prioritisation of institutional reputation management at the expense of silencing marginalised voices and experiences. This article adds to scholarship problematising the taken-for-granted, subjective power wielded by research ethics committees which has the potential to curtail academic freedom and the advancement of knowledge and debate within specific fields. By restricting access to potential participants and through delay tactics, this hindered my ability to carry out the initial research design, shaping the type of data gathered and the knowledge I was able to contribute to this already under-researched area of study.
\end{abstract}

Keywords Research ethics $\cdot$ Research Ethics Committees · University students · Sex work

\section{Introduction}

The 'student by day, sex worker by night' phenomenon has attracted widespread media attention in the UK for over two decades (Busby, 2018; Channel 5, 2019; Hall, 2019; Hough, 2010; Robinson, 2020). It is estimated that 5\%, or approximately 119,000 students, are engaging in some form of sex work while at university (Sagar et al., 2015; Universities UK, 2021). Despite such numbers, Higher Education Institutions (HEIs) have remained overwhelmingly silent on the issue, and academic research is still globally underdeveloped. Sex work has the potential to offer some students more money and flexibility than other

Jessica Simpson

J.Simpson3@1se.ac.uk

1 Sociology, University of Greenwich, London, UK 
'student jobs', and given the growth in sexual commerce and 'appealing content-hosting platforms' (e.g. OnlyFans, AdultWork, Cam4), it is likely that more students (and university faculty/staff, particularly those with insecure contracts) will consider working in the sex industry (see Jones, 2021), highlighting an important gendered ${ }^{1}$ issue in Higher Education (HE) which requires further exploration.

In 2015, as part of my master's thesis on student sex work and negotiations of stigma (see Simpson \& Smith, 2020), I interviewed Danielle, a third-year undergraduate student working as an erotic dancer ${ }^{2}$ in London. At the time, Danielle considered stripping to be a short-term 'student job' that she would leave indefinitely on completion of her degree to then enter a 'graduate job' in her chosen career. Like Danielle, I was also a soon-to-be graduate- but with a part-time job as a waitress - and during the interview, we discussed the hypercompetitive nature of the labour markets. As two working-class women from the North of England, we were concerned that we would not fare as well as other graduates in terms of employment prospects or income after university, and our conversation turned to whether we would be able to leave our waitressing and dancing jobs as easily or quickly as we had anticipated when entering both industries.

In 2016, when I began carrying out my doctoral research, scholarly focus was limited to why students enter the sex industry and their experiences of the work (Roberts et al., 2013; Sagar et al., 2015; Sanders \& Hardy, 2013). My thesis aimed to address a gap in the literature by exploring what happens after university for student sex workers. The research started with a small pilot study and a follow-up interview with Danielle, who, at this point, had lived as a graduate for almost 12 months. By the second interview, we were both still working part-time in our respective 'student jobs'. Danielle started the interview by discussing the challenges she had faced since leaving university which included the breakdown of her long-term relationship, living with her parents again after four years, struggling to find and secure a suitable 'graduate job' and ongoing uncertainty regarding her future. I realised that the experiences she had as a graduate were not exclusive to sex workers and so any claims I made about students/ graduates working in the sex industry could be potentially misleading and suggest that sex workers are somehow unique or different from other graduates. While this may be the case, to be able to identify and explore how working in the sex industry impacts graduate transitions, I chose to look at this comparatively and to also examine what happens after university for students working in 'mainstream' jobs.

The study was limited to students working as erotic dancers which was the most popular form of sex work for students at the time (Sanders \& Hardy, 2013). I also assumed that erotic dancing would be considered a more 'palatable' option that would garner less 'ethical concern' from universities in comparison to other forms of sex work as it is a legal, indirect and relatively normalised form of labour ${ }^{3}$. I chose waitressing ${ }^{4}$ as the mainstream comparator

\footnotetext{
${ }^{1}$ While the sex industry is by no means limited to cis women as workers, the majority of sex workers across all markets are cis women (NSWP, 2017).

${ }^{2}$ Throughout the article, I use the terms erotic dance/dancer/dancing and stripper/stripping and sex work/worker interchangeably which reflects the different and interchangeable terms used by my participants.

${ }^{3}$ The acceptance of stripping in the UK has continued to rapidly decline. There has been a steady increase in the number of cities that have chosen to implement a ban of sexual entertainment venues. This ban is commonly referred to 'nil policy' whereby a local authority refuses to renew licences or grant new licences, effectively closing down the regulated strip industry (e.g. see Wall (2021) for calls to ban strip clubs in Bristol, Drury (2021) for Blackpool and O'Neill (2019) for Glasgow).

${ }^{4}$ When recruiting participants, I used the broader and gender-neutral term 'hospitality worker'; however, all participants referred to their job title as 'waitress'.
} 
because I was familiar with the role through personal experience and due to the similarities shared with stripping. For example, both roles are 'low-skilled', feminised forms of work within the night-time economy that require workers to perform emotional, aesthetic, interactive and sexualised labour (Adkins, 1995; Coffey et al., 2018; Sanders \& Hardy, 2014).

From a labour studies perspective, I was also interested in systematically comparing sex work with mainstream labour as the former is often considered to be inherently exploitative, oppressive and fundamentally different to other forms of employment (Sanders et al., 2013). However, this assertion is not typically based on empirical data, and while there is an existing body of scholarship highlighting the similarities between the labour performed by sex workers and workers in other occupations (see Bernstein, 2007; Ditmore et al., 2010; Lever \& Dolnick, 2010; O'Connell Davidson, 1998; Sanders, 2005), this comparison is discussed in an abstract sense or by combining two separate studies (e.g. Sanders et al.'s (2013) comparison of stripping and hairdressing). Alternatively, my thesis aimed to incorporate the comparison between stripping and waitressing into the research design. By doing so, I do not claim that these jobs are simply one and the same; instead, I look at the similarities and differences between the two roles and ask why these exist and what this means for the theorising of intersectional inequalities within work and employment more broadly.

Following the logic of the pilot study outlined above, my doctoral thesis examined women's transitions through HE in the UK and their experiences of working as strippers or waitresses while studying. Although I did not specify nor limit participation based on gender identity, all 39 participants were cis women. I initially planned to interview final-year students and to re-interview the same women around one year later ${ }^{5}$ as graduates. I sought to uncover how/if women were able to leave their 'student jobs' and their experiences of entering the graduate labour markets. Given the lack of research on the topic of student sex work, I (naively) considered the rationale for the recruitment of students to take part in the research to be both clear and justified. However, the recruitment stage became the most challenging part of the fieldwork and unintentionally produced important findings in and of itself.

This article is a reflexive account of my fieldwork experience which involved being repeatedly blocked and delayed by HEIs across the UK when trying to recruit students as participants from their universities. While scholars have argued that there is a fine line between reflexivity and pointless or narcissistic self-indulgence (Sanchez Taylor \& O'Connell Davidson, 2010), I argue that documenting the challenges we face when carrying out research considered in any way 'controversial' helps to expose and work towards overcoming harmful practices and misuses of power that limit knowledge production. In this sense, reflexivity is not simply self-reflection; it is a pedagogic process that reflects the kind of world that we live in (Ryan-Flood \& Gill, 2010: p. 5). The article begins by situating my fieldwork within the broader scholarly context to demonstrate how attempts by research ethics committees (REC) to block, phase out and undermine my research are neither new nor unique to sexuality researchers. Indeed, scholars working across the social sciences in a wide range of fields have a shared history of negotiating harmful institutional silencing mechanisms. However, by reflecting on my efforts to gain permission to post flyers in universities, I home in on specific examples of resistance from universities, student societies and external student support

\footnotetext{
${ }^{5}$ This was deemed to be an appropriate timeframe given that most data on graduate destinations was - at the time - gathered six months post-graduation. The typical timeframe has since increased, for example, the Higher Education Statistics Agency now aim to capture graduate transitions data around 14-16 months post-graduation (HESA, 2021).
} 
services that are explicitly whorephobic in nature and that function to protect "polished reputations' at the expense of excluding and silencing students who are already routinely ignored and misrepresented (Putnis \& Burr, 2020). The article ends by questioning how we might reimagine and transform problematic academic traditions, codes and practices that delimit other ways of knowing and offers potential 'solutions' that can be implemented by universities to protect student sex workers from unique forms of discrimination, harassment and bullying.

\section{Reflections on carrying out 'dirty' research}

Skeggs (2008) describes academia as a guarded place that not everyone can enter, where knowledge is institutionalised, and bodies, power and privilege are organised and reproduced. Historically, countless fields spanning across the social sciences have suffered ridicule and delegitimation and were pushed to the margins due to their subject matter. This includes but is in no way limited to feminism and gender studies, black and racial studies, indigenous studies, queer and sexuality studies, activist research, criminology or, more broadly, any research involving 'taboo' subjects and with 'non-normative' or 'unloved' groups (see Aldridge et al., 2008; Keim, 2008; Kilty et al., 2014; Pearse et al., 2019; Plummer, 1981; Sanders-McDonagh, 2014; Smith \& Attwood, 2014; Tiefer, 1995). For some scholars, their research area had real and far-reaching consequences with some losing their jobs and others facing legal sanctions, political opposition or even physical violence and threats to their personal safety (Flood et al., 2013).

When reflecting on why my research with student sex workers was blocked by universities, I initially assumed that this was a consequence of sexuality studies' 'dirty past' and that sex work research is still not considered to be legitimate within academe. However, this line of thinking disregards and undermines the work carried out by sexuality scholars to successfully shift their respective disciplines and gain considerable standing. Thanks to the wealth of nuanced, interdisciplinary research produced globally in all the aforementioned fields, we now routinely see scholarship that seeks to challenge and transform previously dominant forms of knowledge production, as well as the mechanisms and protocols that marginalise other ways of knowing (Klein, 2015). Furthermore, such scholarship continues to positively shape public discourse and create more effective laws and policies which also act as clear evidence of the value of researching seemingly 'controversial' topics (Huysamen \& Sanders, 2021). Thus, while the understanding of sexuality research - and other fields - as 'lacking rigour' has not completely disappeared from academia (see Keene, 2021), it is fair to say that such thinking is outmoded. On closer inspection, I realised that I was not necessarily being haunted by a dirty past as much as I was experiencing the effects of present-day whorephobia within HE under the guise of 'research ethics'.

Whorephobia is a term used to describe the hatred, disgust and fear of sex workers - that intersects with racism, xenophobia, classism and transphobia-leading to structural and interpersonal discrimination, violence, abuse and murder. Whorephobia is deeply embedded within societies and is internalised by people of all genders which functions to regulate (namely women's) sexuality and reinforce traditional bourgeois gendered norms (Ellison \& Smith, 2017; Mgbako, 2016; Pheterson, 1993; Schaffauser, 2010). The stigma researchers face through association is in no way comparable to the stigma experienced by those we research. Nevertheless, carrying out sex work research can elicit whorephobic effects which means that 
one of the biggest challenges is coping with other people's reactions to our research topic. Sex work researchers are frequently met with mixed emotions/reactions and/or are not always taken seriously (see Hammond \& Kingston, 2014: p. 340). While distributing flyers including the words 'erotic dancer', I watched as people scoffed and shook their heads disapprovingly. Indeed, the flyers were met with such disdain that three formal complaints were made to my institution's Research Governance and Integrity Manager within the space of a few days. I was also met on numerous occasions with laughter, ridicule and (bad) jokes. For example, I received the following email:

\section{Dear Jess}

I have read your poster and I am rather delighted to hear that you are looking for someone to assist you. With several years of experience in nightclubs all around London, I feel I am the right candidate to evaluate your dance performance and skills. Contact me at any time! (First email).

\section{Dear Jess}

I'm terribly sorry but my friends took the phone and wrote this e-mail, in order to make a joke to me!!! (Second email, 10 minutes later).

When attempting to gather (more) evidence that the research was covered by my institution's insurance policy, I was accidentally copied into an email that read, 'A request for insurance approval please - but this one is slightly out of the ordinary!' At every stage, the research received a (negative) reaction of some sort which in this case appears to be either another joke, a sense of shock or even a forewarning to the insurer. Similarly, when ordering sex workrelated books and resources to the library, I was told by a member of staff (cis man) that I had caused 'quite a stir ordering these types of books', that everyone was talking about 'the person who had ordered loads of books on strippers' and that he did not usually read 'the boring books on finance' but that he, and others, 'had made sure to have a flick through' mine. I was then asked why I was interested in the topic and whether I had worked in the sex industry.

I am frequently asked if I am a sex worker, and I have heard countless anecdotal stories from other researchers who have been asked the same question or subjected to similar assumptions. Would this 'justify' our interest? Or, as Price-Glynn (2010: p. 199) argues, are such questions for titillation rather than substance? As I am studying two occupations, this question reveals that this is not random. During the full research process, I was never asked why I am interested in waitressing. Even if sex work researchers were/are working in the sex industry - as many have done and continue to do so - why should this delegitimise the subject of their research given the clear advantages of insider knowledge? (Bruckert, 2014; Colosi, 2012; Lister, 2015; Pilcher, 2017).

When I began the recruitment process, I was advised by colleagues and mentors to find work as a dancer to provide access to potential respondents. While the researcher's body is typically absent from discussions of fieldwork, as if they are somehow disembodied (for exceptions, see Ellingson, 2006; Harris, 2015; Hordge-Freeman, 2018), my body and appearance came under constant scrutiny throughout the research process. I noticed that people would scan my body before asking if I was or had been a stripper and I felt forced to reflect on why, as a young, able-bodied woman, I did not at least audition for the role, especially 
considering that I had worked as a waitress prior to and throughout my doctoral research. As stripping involves displaying the naked body, I found myself evaluating specific parts of my body and questioning the meanings I attached to my appearance which I found to be an uncomfortable process. I realised that regardless of how I felt about my body, the assumption that I — or indeed any woman — can simply find work as a dancer ignores the stringent rules on appearance within strip clubs and devalues the skills required to work in the industry. Although there is variation among strippers, there is also an industry standard and research has continued to show the immense pressures some dancers face in trying to obtain/maintain the stereotypical 'stripper look' (Bradley, 2008: p. 509; Bradley-Engen \& Ulmer, 2009). During the interview stage, I found that several women were refused work in strip clubs and pubs based on their appearance and due to their weight in particular, with some women considered 'too fat' and others 'too thin'. Nevertheless, this reflexive process was an affective, emotional and embodied experience that shaped the knowledge I was able to produce as I chose not to audition. Instead, I contacted universities and requested to post research flyers in communal areas used by students. Unfortunately, this decision also hindered knowledge production, and what follows demonstrates that despite claims that universities are 'equal, diverse and inclusive', this sense of inclusion does not extend to all students.

\section{Research ethics or whorephobia?}

\section{University response}

My research was ethically approved by my institution's REC in 2016 following an extensive review. Based on my own institution's guidelines for external researchers wishing to recruit participants from the student body, I contacted the ethics committees (or equivalent) of universities across the UK requesting permission to post flyers in areas of the university that they deemed to be appropriate and/or via student mailing lists. To 'prove' that my research was credible, the email request included:

1. A justification for why students from said university needed to be recruited for the study

2. A copy of my completed ethics application form

3. Evidence that the study had received ethical approval

4. Copies of consent forms and information sheets

5. Details of intended recruitment methods

6. Copies of both flyers

7. Evidence that suitable insurance arrangements were in place

I found there was a general reluctance among most universities to provide a yes or no response to my request. I was repeatedly asked for additional evidence to verify that my research was legitimate and that I was a credible researcher. While one university (see University C) assured me they 'believed' I was 'perfectly responsible etc.', similar to Keene's (2021) experience of not being taken seriously and being considered 'naïve', I questioned whether, as a young woman carrying out doctoral research, if I was also facing additional, hidden and gendered barriers. It was clear that individual members of staff did not want to be held accountable for the decision which meant that I was frequently directed to more senior members of staff and/or to different departments to have any decision seconded. Overall, I found such responses to be 
delaying/time-wasting exercises as ultimately the answer was no. On the whole, universities feared the potential reaction the flyers could provoke internally/externally and denied my request as a means of avoiding liability. I have included the following (anonymised) extracts from emails I received from universities to demonstrate the point further.

[University A] is not able to approve your request to advertise your research in the College. Under our research ethics policy, this project would be classified as extremely sensitive and would require approval by the full College Ethics Committee. (own emphasis, University A)

I will need to discuss with the sabbatical officers if they are okay to have this advertised in their communal areas, but I don't know what the chances of anyone responding are given it is such a sensitive issue. (University B)

Your request is simple enough. However, I am not willing to take responsibility for your engagement at [University $\mathrm{C}$ ], even though I am sure you are a perfectly responsible, etc. individual. (University C)

Generally, we are open to helping researchers from other universities but in this case, I am afraid we cannot. While I perfectly understand that this is a legitimate area of research there is a potential problem of managing responses to the proposed posters. If this were a [University D] project we would not have such posters and we would ask the researcher to develop other, less public, forms of recruitment. These posters might, potentially, give offense to some students/ staff and we would have no way of giving an explanation of why they are necessary/important or how they have been approved. I am sorry that [University D] cannot help with this research but I cannot approve, in the name of the university, this recruitment of our students on campus. (University D)

Thank you for providing confirmation that City University's Research Ethics Committee has ethically approved your study and that all aspects of your research are covered by [University's] insurance brokers. However, given the sensitive nature of the research, Professor $\mathrm{X}$ has declined to grant approval for you to recruit [University E] undergraduate students to your study. (University E)

I was granted permission to post flyers in one Central London university (in elevators, toilets, message boards, etc.). However, the flyers targeting erotic dancers were defaced, ripped down and left on the floor or put in the bin. I am unable to say with certainty whether this was by students, staff or both. I attempted to re-post the same flyers on several occasions to find the same thing happen again. The flyers were posted alongside other student projects requesting participants for what could also be deemed 'sensitive' research, for example, research on experiences of cancer, mastectomies and alcoholism. Nevertheless, it was experiences of working as an erotic dancer while studying that students/staff considered to be so unacceptable that almost all the flyers were taken down without permission. After discussing this issue with several members of staff and other students, I found that the tearing down of research flyers is not commonplace at the university and was told that students carrying out 'normal' research do not usually have these problems.

While there are many definitions of what constitutes 'sensitive research', except for University D, it is unclear what it is about the project that rendered it (extremely) sensitive. Was it the topic itself? The methodological approach? The potential consequences of the research? However, what is clear is that labelling the research 'sensitive' acts as a guise that ostensibly relieves institutions of their responsibility to remain transparent and to provide any further explanation of why the flyers were rejected. Although it is widely acknowledged that RECs are increasingly 'risk-averse' (Huysamen \& Sanders, 2021), by unpacking and problematising the taken-for-granted logic behind this 'justification' to reject the flyers, this 
exposes further hidden meaning (Parpart, 2010: p. 24). For example, the response I received from universities, combined with the ongoing institutional silence regarding student sex work more broadly, suggests a 'wilful ignorance' (Skeggs, 2019: p. 28). HEIs are stubbornly resisting what they do not want to hear or see, while simultaneously blocking attempts to generate knowledge on the topic. This silence does not free institutions from liability but instead sheds light on deeply embedded intersectional inequalities as such issues can only be ignored by those with enough privilege to ignore them. Importantly, attempts to block research or publicity relating to student sex work should not be seen as distinctive or individual responses from certain HEIs (Sagar et al., 2015: p. 401). Silencing mechanisms can have a damaging effect leading to an unwillingness to carry out research on certain topics which could explain why student sex work remains under-researched in the UK and globally. More broadly, there are several unreported, anecdotal examples of prospective $\mathrm{PhD}$ researchers who were advised by senior members of staff in different universities that researching the sex industry will inhibit their academic career (Roberts, 2018: p. 61).

The explanation provided by University D was more explicit and reinforces broader whorephobic discourse in three ways. Firstly, by identifying a key 'risk' of the flyers to be potentially offending some staff/students, this positions sex workers as 'offenders against decency' (Schaffauser, 2010) or as a 'public nuisance' (Putnis \& Burr, 2020). Secondly, the 'advice' to find 'less public' forms of recruitment implies that the university would prefer student sex workers to also remain hidden, contributing to the longstanding exclusion of sex workers from public space. Thirdly, the claim that 'there would be no way of explaining why the flyers were necessary or important' also suggests that the experiences of student sex workers are 'Other' and unimportant or at least not of equal importance to student matters more generally. However, based on recent research (see Ernst et al., 2021; Hammond, 2019; Simpson \& Smith, 2020), it is now incontestable that a substantial number of students are involved in some form of sex work while at university. This means that the ongoing assertion that 'there are no student sex workers at this institution' is no longer acceptable. If universities consider research that has been granted ethical approval to be 'too sensitive', 'potentially offensive' or a 'reputational threat' (see Cusick et al., 2009), this raises serious concern regarding the stance the same universities take towards their own students working in the sex industry (Sagar et al., 2016).

To date, the majority of HEIs have responded to student sex work by either ignoring the issue, taking a paternalistic approach with the aim of 'rescuing' students from the sex industry or by punitively excluding students for engaging in legal work to (ironically) pay their way through university (see Lister, 2019). Such whorephobic responses from HEIs can endanger students' lives, health and wellbeing if/when they feel unable to access support due to fear of disciplinary action, stigmatisation and exclusion (Platt et al., 2018). I join Cusick et al. (2009), Sagar et al. (2016), Roberts (2018) and Lister (2019) in calling upon universities to not only break their overwhelming silence on the issue but to actively respond to the unique forms of discrimination faced by student sex workers.

\section{Students' Unions and student societies}

I assumed that 'convincing' Students' Unions and student societies to share my recruitment poster would be easier than contacting universities, particularly as the National Union of Students (2016) had published a report urging Students' Unions and HEIs to support student sex workers specifically and had publicly supported the decriminalisation of sex work more 
broadly. While I was able to distribute flyers in four London Students' Unions and one Students' Union outside of London agreed to post the flyer via social media, others appeared to share similar sentiments to HEIs.

Due to the nature of your flyers and the subject content we would deem these as inappropriate for distribution in our venue. (email from London-based Students' Union)

I'm afraid that anyone associated with being a stripper is asked to leave our club as we are a sports club. May be best to email strip clubs directly. (email from pole fitness societyUniversity G)

Unfortunately, as a University Society we have been working hard to shake off the idea that all pole dancers are strippers and sharing your flyer with our members would mean compromising that image. Although all our members are fully aware that not all pole dancers are strippers, the problem is not everyone on Facebook thinks the same way. I hope you understand that although we would love to help, we can't put our Society in such a delicate position. (email from pole fitness society-University $\mathrm{H}$ )

The deeply embedded and internalised nature of whorephobia is demonstrated by the clear effort made by the student-led societies to avoid the stain of whore stigma (Pheterson, 1993). Despite appropriating pole dance from strippers, the societies attempted to 'shake off' and clean up the associated dirt due to fear of reputational damage, a fear that evidently extends to all spheres of the university. At the time of research, similar attempts to distance pole fitness from stripping had also become popular on social media - using \#NotAStripper - which reinforces the harmful good girl (read: pole fitness) and bad girl (read: stripper) divide that polices women's sexuality and behaviour. Importantly, the exclusion of 'anyone associated with being a stripper' highlights how whore stigma spoils a woman's identity and becomes her master status (Bruckert, 2014). In this instance, women are no longer students with part-time jobs as strippers but rather strippers who are not welcome in student spaces. Student sex workers are at risk of bullying, harassment and abuse, and the extracts above serve as another reminder that universities have a duty of care and responsibility to ensure that their campuses are safe and inclusive spaces for all students.

\section{External student support services}

Given the whorephobic response I had received thus far, I decided to change my approach and post the researcher flyers on a popular student forum that was not directly related to any university, but that claimed to have one of the largest online student communities. The research was specifically posted on the 'Student Surveys and Research' thread which was described as 'A place to post dissertation surveys and other academic research'. All posts must be approved by a moderator before they are visible to other users. Within 24 hours, the flyer targeting waitresses was accepted; however, the flyer for erotic dancers was declined and removed from the forum. I contacted the moderator via email to reassure the organisation that I was a student, that I had posted the flyers in the appropriate thread and that stripping is a legal form of labour in the UK and to ask why one flyer was approved and the other was declined/ removed. I received the following response.

Thanks for contacting us. Your post, which is requesting interviews from students who worked as erotic dancers, does not meet our community guidelines. Although we allow an open discussion around sex and relationships on our site, this, unfortunately breaks our guidelines as we are ultimately an educational site. (Student Forum) 
On the same day, and without explanation, the flyer targeting waitresses was also removed from the forum. Following this attempt to block my research/recruitment, I replied to the organisation to clarify that many sex workers do not associate either sex or relationships with their work (Sanders, 2005: pp. 327-328), and while erotic dancing involves sexualised labour/ interactions, like many other forms of mainstream labour, this should not restrict this form of labour to such discussions. I checked the community guidelines before posting the flyer and requested further information as it was not clear how the flyers were not in compliance with any of the rules or regulations set out on the website. I agreed that the student forum is an educational website whereby students sign up and post advice, comments and requests to one another - creating content and (indirectly) revenue for the organisation - regarding educational matters. I was then told that the flyer to recruit waitresses would be put back onto the forum that day and that there would be 'further discussion' regarding the flyer for erotic dancers. The student forum also offered some 'advice' regarding my recruitment methods which was the most telling of the actual problem.

What I would advise is that members of [the student forum] community are unlikely to have worked in the industry, so you may not get the response you expect, and you would most likely be far more successful sourcing your research from another forum. (Student forum)

The response above mirrors that of HEIs as there is an assumption/assurance that none of their members/students are sex workers, followed by 'advice' to take my research elsewhere. This is yet another example of how whorephobia functions to affect a fearful reaction to the research. Removing the flyer signals an attempt to also remove the potential threat of association with sex work and any subsequent negative media attention/reputational damage. Unfortunately, this fear of media backlash is not unfounded, particularly for universities that have been publicly labelled 'pimps' and accused of pushing students into the 'most dangerous profession on the planet' (Coburn, 2021). In 2018, one UK university was targeted by anti-prostitution activists when their Students' Union invited a sex worker outreach project to offer advice and support to students at a Freshers' Fair (Busby, 2018). Rather than backing the Students' Union in their decision, the university in question fuelled this misinterpretation and responded by launching an investigation, disassociating from the decision and making a clear statement that the university does not promote sex work as an option for students. As previously mentioned, such responses from universities can have real and damaging consequences if/when students feel unable to seek support from their universities due to fear of stigma or punitive consequences.

\section{Breaking (harmful) 'traditions'}

When discussing power imbalances within the research process, focus tends to be geared towards redressing the unequal researcher-researched dyad leaving other forces of patriarchal power unquestioned, namely, that of 'ethical regulation' and RECs. The aim of this article is not to discount the importance of ethical review per se, but rather, to challenge the misuse of 'ethics'. As an individual researcher, it is extremely difficult to argue against 'ethics' (which are essentially principles designed to protect and prevent harm) and even more difficult to challenge powerful institutions if/when they exploit ethical regulatory processes due to fear of becoming subjects of research themselves and/or fear that any association with student sex work could mar their polished image (Phipps, 2021). Boden et al. (2009) argue that there is a common (mis)understanding of ethics and the role of ethics committees as upholding clear, objective, highly scripted sets of rules and procedures which masks the subjective nature of 
ethical (dis)approval. Indeed, I frequently experienced individual professors rejecting my request (for example, see University E above), and universities referring to 'our' research ethics, separating their ethical code from that of my own institution. In such instances, it is important to ask who has the power to decide what is and is not ethical and, thus, what research is considered (in)appropriate?

Restricting access to potential respondents not only hindered my ability to carry out the initial research design but also shaped the knowledge that I was able to produce. Blocking certain research projects can uphold particular-gendered, racialised and classed-views of the world and ultimately shape disciplines. For example, I was able to recruit several students working as erotic dancers via a sex work collective. However, as they were politically motivated to improve the working conditions within the sex industry, their commitment to stripping may not reflect the perspectives of students more broadly, who may be less invested or have different experiences and who may consider the work to be more transient. Thus, what is at stake here is epistemic power and the politics of knowledge (Skeggs, 2008) making this part of a much broader fight against the dominant mechanisms, protocols and discourses within HE that continue to marginalise other ways of knowing and that contribute to the perpetuation of injustices (i.e. gender, colonial and environmental, among others (see Temper et al., 2019). Without research on 'politically sensitive' topics, we are unable to fully understand or 'solve' social problems. Agustin (2005) argues that those without moralistic views on sex work consider generating a deeper understanding of the cultural meanings of sex (in its broadest sense of the term) to be an obvious and positive contribution to knowledge,

[Yet] ...even those who believe sex should never be commercialised, research into its meanings should be important, for how will society stop, 'control' or otherwise govern such widespread activity without understanding how and why it goes on?, (Agustin, 2005: p. 627)

Fifteen years ago, Popke (2006 cited in King, 2021: p. 2) estimated that around 1,500 articles were published in academic journals each year concerning and critiquing the role of RECs. There is now an extensive - and growing - literature in this area from scholars in a wide range of disciplines, and yet, the only trend we have witnessed has been towards an increase in the pre-emptive, formalistic and bureaucratic regulation of research (Glucksmann, 2010). The very nature of research and education has been reformulated by toxic conditions of neoliberal academia, and as the university becomes more corporatised and privatised, 'risk management' becomes financial management (Gill, 2010: p. 231). Regarding the research discussed throughout this article, it appears that efforts to obviate potential causes of litigation against the institution become the main concern, rather than that of ethics or harm to research participants. Hedgecoe (2016) argues that we should expect more and harsher restrictions on research which will threaten academic freedom and the future of social research. There are clear implications for researchers if/when they limit themselves to projects that will 'get through' ethics committees, rather than focusing on producing research that is ethically justifiable and of socio-political importance (Hammersley, 2009).

My 'failed' attempts at jumping through countless institutional hoops to justify my research and prove that I was a credible researcher demonstrate how 'playing the game' poses no challenge to the current, unequal system and instead reinforces its power. Galvez and Muñoz (2020) argue that researchers can - often unintentionally - become active participants in replicating colonial, patriarchal and white supremacist practices when we uphold scholarly traditions, codes and sets of ethics. If we want to incite positive change, we must open ourselves up to the possibility of different alternatives and to bringing these to life. As Audre Lorde (1984) famously stated, the master's tools will never dismantle the master's house and so we must carry out the thorny work involved in collectively building a different house (Phipps, 
2021). Galvez and Muñoz (2020) anti-colonial manifesto is one of many examples of how we might reimagine the ethics process. The authors challenge the typical top-down approach applied within HE and instead foreground reciprocity with the communities that we serve. While universities, researchers, and participants often have conflicting interests, by collaboratively addressing differences in values and power, it is argued that this can help to ensure that marginalised — rather than institutional—voices and needs are prioritised. Similarly, and regarding sex work research specifically, Huysamen and Sanders (2021) also suggest coproducing research ethics protocols with sex work communities to set out their expectations and the conditions under which they would like to work with researchers. While this logic can be applied to a wide range of communities, one important and potentially transformative outcome of students working in the sex industry is that we have sex workers who are claiming academic space and authority with increasing frequency (Bruckert, 2014). This presents an exciting opportunity for students and staff to work together not only to imagine new ways of carrying out research, but also in developing ways to facilitate cultural change.

The examples discussed throughout this article demonstrate how whorephobia is reproduced and how it functions within HE, making the university a hostile place for student sex workers. Since I completed my doctoral research, there have been positive shifts within the sector, and several UK universities have developed policies, toolkits and sources of support for students and staff working in the sex industry (for example, see University of Leciester, 2021). While it is essential that all universities break their silence and implement similar measures to protect student sex workers from unique forms of bullying, harassment and abuse, at the same time, creating policies can allow institutions to look like they are doing something about an issue, or to claim that the issue has already been addressed, which in turn allows them to not do anything else (Phipps, 2021). Alongside a lack of specific responses necessary to support students engaged in sex work, more broadly, HEIs and governments are wide of the mark in their understanding of the lived realities of all working students. The current financial support available to students does not reflect the employment pressures faced by many, particularly those with multiple roles/responsibilities or those working due to economic necessity and who are consequentially vulnerable to exploitative and harmful working conditions and practices (see Simpson, 2020; Simpson \& Crossley, forthcoming). Universities and governments must provide all students with proper financial support to ensure that they are able to participate within the HE system as equals and that all work - sex work or otherwise - is carried out willingly, as a form of supplementary income and not to simply survive.

\section{Declarations}

Ethics approval The author received full ethical approval from City, University of London and was granted informed consent from all 39 participants.

Conflict of interest The author declares no competing interests.

Open Access This article is licensed under a Creative Commons Attribution 4.0 International License, which permits use, sharing, adaptation, distribution and reproduction in any medium or format, as long as you give appropriate credit to the original author(s) and the source, provide a link to the Creative Commons licence, and indicate if changes were made. The images or other third party material in this article are included in the article's Creative Commons licence, unless indicated otherwise in a credit line to the material. If material is not included in the article's Creative Commons licence and your intended use is not permitted by statutory regulation or exceeds the permitted use, you will need to obtain permission directly from the copyright holder. To view a copy of this licence, visit http://creativecommons.org/licenses/by/4.0/. 


\section{References}

Adkins, L. (1995). Gendered work: Sexuality, family and the labour market. Open University Press.

Agustin, M. L. (2005). New research directions: The cultural study of commercial sex. Sexualities, 8(5), 618631.

Aldridge, J., Medina-Ariza, J., \& Ralphs, R. (2008). Dangers and problems of doing 'gang' research in the UK. In F. V. Gemert, D. Peterson, \& I. Lein (Eds.), Street gangs, migration and ethnicity (pp. 31-46). Willan Publishing.

Bernstein, E. (2007). Sex work for the middle classes. Sexualities, 10(4), 473-488.

Boden, R., Epstein, D., \& Latimer, J. (2009). Accounting for ethos or programmes for conduct? The brave new world of research ethics committees. The Sociological Review, 57(4), 727-749.

Bradley-Engen, M. S., \& Ulmer, J. T. (2009). Social worlds of stripping: The processual orders of exotic dance. The Sociological Quarterly, 50(1), 29-60.

Bradley, M. S. (2008). Stripping in the new millennium: Thinking about trends in exotic dance and dancers' lives. Sociology Compass, 2(2), 503-518.

Bruckert, C. (2014). Activist academic whore: Negotiating the fractured otherness abyss. In J. Kilty, M. FelicesLuna, \& S. C. Fabian (Eds.), Demarginalizing voices: Commitment, emotion and action in qualitative research (pp. 306-325). UBC Press.

Busby, E. (2018) University launches investigation into sex work support group's stall at freshers' fair. [Online] Available at:https://www.independent.co.uk/news/education/education-news/sex-work-students-brightonuniversity-sussex-freshers-fairswop-a8563186.html. Accessed 26 June 2020.

Channel 5. (2019). Student sex workers - Channel 5. [Online] Available at: https://www.channel5.com/show/ student-sex-workers/. Accessed 31 Aug 2019.

Coburn, P. (2021) Why are universities so keen to support prostitution? [Online] Available at: https://www. unherd.com/thepost/whyare-universities-so-keen-to-support-prostitution/. Accessed 26 June 2021.

Coffey, J., Farrugia, D., Adkins, L., \& Threadgold, S. (2018). Gender, sexuality, and risk in the practice of affective labour for young women in bar work. Sociological Research Online, 23(4), 728-734.

Colosi, R. (2012). Dirty dancing? Willan Publishing.

Cusick, L., Roberts, R., \& Paton, S. (2009). Higher and further education institution policies on student and staff involvement in commercial sex. Journal of Higher Education Policy and Management, 31(2), 185-195.

Ditmore, M. H., Levy, A., \& Willman, A. (2010). Sex work matters. Zed.

Drury, C. (2021) Strictly no lap dancing: Blackpool to ban strip clubs in bid to clean up image. [Online] Available at: https://www.independent.co.uk/news/uk/home-news/blackpool-lap-dancing-clubs-banb1826320.html. Accessed 4 July 2021.

Ellingson, L. L. (2006). Embodied knowledge: Writing researchers' bodies into qualitative health research. Qualitative Health Research, 16(2), 298-310.

Ellison, G., \& Smith, L. (2017). Hate crime legislation and violence against sex workers in Ireland: Lessons in policy and practice. In A. Haynes, J. Schweppe, \& S. Taylor (Eds.), Critical Perspectives on Hate Crime. Palgrave Macmillan. https://doi.org/10.1057/978-1-137-52667-0_10.

Flood, M., Martin, B., \& Dreher, T. (2013). Combining academia and activism common obstacles and useful tools. Australian Universities Review, 55(1), 17-26.

Gill, R. (2010). Breaking the silence: The hidden injuries of the neoliberal university. In R. Ryan-Flood \& R. Gill (Eds.), Secrecy and silence in the research process: feminist reflections (pp. 228-244). Routledge.

Galvez, E., Muñoz, S., \& M. (2020). (Re)Imagining anti-colonial notions of ethics in research and practice. Journal of College Student Development, 61(6), 781-796.

Glucksmann, M. (2010). Silence by law: The cautionary tale of the woman on the line. In R. Ryan-Flood \& R. Gill (Eds.), Secrecy and silence in the research process: Feminist reflections (pp. 200-208). Routledge.

Hall, J. (2019). Student sex workers reveal the problems they face at Uni. [online] Vice. Available at: <https:// www.vice.com/en_uk/article/qv7bpq/student-sex-workers-reveal-the-problems-they-face-at-uni>. Accessed 29 April 2019.

Hammersley, M. (2009). Against the ethicists: On the evils of ethical regulation. International Journal of Social Research Methodology, 12(3), 211-225.

Hammond, E. (2019). The labour of paying for education: An exploration of student sex work in Canada. MA Thesis. https://www.curve.carleton.ca/dbdff3bc-35ad-404d-b193-2bc18fa55e73. Accessed 26 June 2021.

Ernst, F., Romanczuk-Seiferth, N., Köhler, S., Amelung, T., \& Betzler, F. (2021). Students in the sex industry: Motivations, feelings, risks, and judgments. Frontiers in Psychology, 12, 586235.

Hammond, N., \& Kingston, S. (2014). Experiencing stigma as sex work researchers in professional and personal lives. Sexualities, 17(3), 329-347.

Harris, M. (2015). 'Three in the Room': Embodiment, disclosure, and vulnerability in qualitative research. Qualitative Health Research, 25(12), 1689-1699. 
Hedgecoe, A. M. (2016). Reputational risk, academic freedom and research ethics review. Sociology, 50(3), 486501.

HESA. (2021). https://www.hesa.ac.uk/innovation/outcomes/providers/timing. Accessed 26 June 2020.

Hordge-Freeman, E. (2018). "Bringing your whole self to research" The power of the researcher's body, emotions, and identities in ethnography. International Journal of Qualitative Methods, 17(1), 1-9.

Hough, A. (2010). Oxbridge sex blogger lifts lid on university love life. [Online] Available at: https://www. telegraph.co.uk/news/newstopics/howaboutthat/7264351/Oxbridge-sex-blogger-lifts-lid-on-university-lovelife.html. Accessed 26 June 2020.

University of Leciester (2021). Student sex work. [Online] Available at https://www.reportandsupport.le.ac.uk/ support/student-sex-work. Accessed 3 June 2021.

Huysamen, M., \& Sanders, T. (2021). Institutional ethics challenges to sex work researchers: committees, communities, and collaboration. Sociological Research Online. https://doi.org/10.1177/ 13607804211002847.

Jones, A. (2021). It's time for universities and colleges to acknowledge and support student sex workers. [Online] Available at: https://www.drjonessoc.medium.com/its-time-for-universities-and-colleges-to-acknowledgeand-support-student-sex-workersa0934032b6de. Accessed 26 June 2021.

Keene, S. (2021). Becoming a sexademic: Reflections on a 'dirty' research project. Sexualities. https://doi.org/10. $1177 / 1363460720986915$.

Keim, W. (2008). Social sciences internationally: The problem of marginalisation and its consequences for the discipline of sociology. African Sociological Review, 12(2), 22-48.

Kilty, J., Felices-Luna, M., Fabian, S., \& C. (Eds.). (2014). Demarginalizing voices: Commitment, emotion and action in qualitative research. UBC Press.

King, G. (2021). Towards a culture of care for ethical review: Connections and frictions in institutional and individual practices of social research ethics. Social \& Cultural Geography. https://doi.org/10.1080/ 14649365.2021.1939122.

Klein, J. T. (2015). Reprint of "Discourses of transdisciplinarity: Looking back to the future". Futures, 65, 1016.

Lever, J., \& Dolnick, D. (2010). Call girls and street prostitutes: Selling sex and intimacy. In R. Weitzer (Ed.), Sex for sale: Prostitution, pornography, and the sex industry (2nd ed., pp. 187-203). Routledge.

Lister, B. (2015). Shifting power relations within the Scottish lap-dancing industry. Graduate Journal of Social Science, 11(2), 38-54.

Lister, K. (2019). 'I was threatened with expulsion': Why sex workers at university fear speaking out. [Online] Inews. Available at: https://inews.co.uk/opinion/comment/studentssex-work-university-policies-502375. Accessed 26 May 2019.

Lorde, A. (1984). The master's tools will never dismantle the master's house (Comments at the "The personal and the political panel," Second Sex Conference, New York, September 29, 1979). In Sister outsider (pp. 110-113). Sister Visions Press (Original work published 1979).

Mgbako, C. A. (2016). To live freely in this world: Sex worker activism in Africa. New York University Press.

National Union of Students. (2016). Student sex worker research. NUS.

Network of Sex Work Projects. (2017) Policy brief: Sex work and gender equality. [Online] Available at: https:// www.nswp.org/sites/nswp.org/files/policy_brief_sex_work_and_gender_equality_nswp_2017.pdf. Accessed 26 June 2021.

O'Connell Davidson, J. (1998). Prostitution, power and freedom. Polity Press.

O’Neill, C. (2019) Council seeks views on banning strip clubs in Glasgow as consultation enters final days. [Online] Available at: https://www.glasgowlive.co.uk/news/glasgow-news/council-seeks-views-banningstrip-16790770. Accessed 26 June 2021.

Parpart, J. (2010). Choosing silence: Rethinking voice, agency and women's empowerment. In R. Ryan-Flood \& R. Gill (Eds.), Secrecy and silence in the research process, feminist reflections (pp. 15-29). Routledge.

Pearse, R., Hitchcock, J., Keane, N., \& H. (2019). Gender, inter/disciplinarity and marginality in the social sciences and humanities: A comparison of six disciplines. Women's Studies International Forum, 72, 109126.

Pheterson, G. (1993). The whore stigma: Female dishonor and male unworthiness. Social Text, 37(winter), 3964.

Phipps, A. (2021). Tackling sexual harassment and violence in universities: Seven lessons from the UK. [Online] Available at: https://phipps.space/2021/02/05/seven-lessons/. Accessed 26 June 2021.

Pilcher, K. (2017). Erotic performance and spectatorship: New frontiers in erotic dance. Routledge.

Platt, L., Grenfell, P., Meiksin, R., et al. (2018). Associations between sex work laws and sex workers' health: A systematic review and meta-analysis of quantitative and qualitative studies. PLoS Medicine, 15(12). https:// doi.org/10.1371/journal.pmed.1002680.

Plummer, K. (Ed.). (1981). The making of the modern homosexual. Barnes and Noble. 
Popke, J. (2006). Geography and ethics: Everyday mediations through care and consumption. Progress in Human Geography, 30(4), 504-512. https://doi.org/10.1191/0309132506ph622pr.

Price-Glynn, K. (2010). Strip club: Gender power and sex work. New York University Press.

Putnis, N., \& Burr, J. (2020). Evidence or stereotype? Health inequalities and representations of sex workers in health publications in England. Health, 24(6), 665-683.

Roberts, R. (2018). Capitalism on campus: Sex work, academic freedom and the market. Zero Books.

Roberts, R., Jones, A., \& Sanders, T. (2013). Students and sex work in the UK: Providers and purchasers. Sex Education:Sexuality. Sex Education:Sexuality, Society and Learning, 13(3), 349-363.

Robinson, A. (2020). Coronavirus: More students are turning to sex work during COVID-19 pandemic. [Online] Available at: https:/news.sky.com/story/coronavirus-more-students-are-turning-to-sex-work-during-covid19-pandemic-12066700. Accessed 10 September 2020.

Ryan-Flood, R., \& Gill, R. (Eds.). (2010). Secrecy and silence in the research process: Feminist reflections. Routledge.

Sagar, T., Jones, D., Symons, K., Bowring, J., \& Roberts, R. (2015). Student participation in the sex industry: Higher education responses and staff experiences and perceptions. Journal of Higher Education Policy and Management, 37(4), 400-412.

Sagar, T., Jones, D., Symons, K., Tyrie, J., \& Roberts, R. (2016). Student involvement in the UK sex industry: Motivations and experiences. The British Journal of Sociology, 67(4), 697718.

Sanchez Taylor, J., \& O’Connell Davidson, J. (2010). Unknowable secrets and golden silences: Reflexivity and research on sex tourism. In R. Ryan-Flood \& R. Gill (Eds.), Secrecy and silence in the research process: feminist reflections (p. 4253). Routledge.

Sanders-McDonagh, E. (2014). Conducting "dirty research" with extreme groups: Understanding academia as a dirty work site. Qualitative Research in Organizations and Management: An International Journal, 9(3), $241-253$

Sanders, T. (2005). 'It's just acting': Sex workers' strategies for capitalizing on sexuality. Gender, Work and Organization, 12(4), 319-342.

Sanders, T., \& Hardy, K. (2013). Students selling sex: Marketisation, higher education and consumption. British Journal of Sociology of Education, 36(5), 747-765.

Sanders, T., \& Hardy, K. (2014). Flexible workers: Labour, regulation and the political economy of the stripping industry. Routledge.

Sanders, T., Cohen, R. L., \& Hardy, K. (2013). Hairdressing/undressing: Comparing labour relations in selfemployed body work. In C. Wolkowitz, R. L. Cohen, T. Sanders, \& K. Hardy (Eds.), Body/Sex/work: intimate, embodied and sexualised labour (pp. 110-126). Palgrave Macmillan.

Schaffauser, T. (2010). Whorephobia affects all women. [Online] Available at: https://www.theguardian.com/ commentisfree/2010/jun/23/sex-workers-whorephobia. Accessed 26 June 2021.

Simpson, J. (2020). Degrees on the side: Student employment and the neoliberal university. Soundings, 76. https://doi.org/10.3898/SOUN.76.05.2020.

Simpson, J., \& Crossley, H. (forthcoming). "It's (not) part of the job": Student negotiations of sexual harassment in hospitality. Gender and Society.

Simpson, J., \& Smith, C. (2020). Students, sex work and negotiations of stigma in the UK and Australia. Sexualities, 24(3), 474-490.

Skeggs, B. (2008). The dirty history of feminism and sociology: Or the war of conceptual attrition. The Sociological Review, 56(4), 670-690.

Skeggs, B. (2019). The forces that shape us: The entangled vine of gender, race and class. The Sociological Review, 67(1), 28-35.

Smith, C., \& Attwood, F. (2014). Anti/pro/critical porn studies. Porn Studies, 1(1-2), 7-23.

Temper, L., McGarry, D., \& Weber, L. (2019). From academic to political rigour: Insights from the 'tarot' of transgressive research. Ecological Economics, 164, 106379.

Tiefer, L. (1995). Sex is not a natural act and other essays. Westview Press.

Universities UK (2021). Higher education in numbers. [Online] Available at: https://www.universitiesuk.ac.uk/ facts-andstats/Pages/higher-education-data.aspx. Accessed 26 June 2021.

Wall, T. (2021). Gender equality activists hail Bristol council's vote on ban for strip clubs. [Online] Available at: https://www.theguardian.com/uk-news/2021/mar/14/gender-equality-activists-hail-bristol-councils-vote-onban-for-strip-clubs. Accessed 4 July 2021.

Publisher's note Springer Nature remains neutral with regard to jurisdictional claims in published maps and institutional affiliations. 